\title{
CARRYING CAPACITY AND LAND SUITABILITY OF RICE FIELDS ON THE SPATIAL PLANNING OF PANGKAJENE URBAN AREA
}

\author{
Reza Asra', Andi Ayu Nurnawati', Muh. Faisal MF³, Aksal Mursalat ${ }^{4}$ \\ 1,2Agrotechnology Department, Muhammadiyah University of Sidenreng Rappang \\ Jl. Angkatan 45 No. 1 A Tel. (0421) 93308 Lt. Salo, Sidenreng Rappang, South Sulawesi \\ ${ }^{3}$ Forestry Department, Maros Muslim University \\ Jl. DR. Ratulangi No.62 Tel (0411) 8938018 Maros, South Sulawesi \\ ${ }^{4}$ Agribusiness Department, Muhammadiyah University of Sidenreng Rappang \\ Jl. Angkatan 45 No. 1 A Tel. (0421) 93308 Lt. Salo, Sidenreng Rappang, South Sulawesi
}

Email corresponding: rezaasraahmad@gmail.com

\begin{tabular}{|c|c|c|}
\hline Submitted: & Accepted: & Published: \\
$29-09-2020$ & $28-11-2020$ & $31-01-2021$ \\
\hline
\end{tabular}

\begin{abstract}
The growth of an urban area will result in the conversion of agricultural land to nonagricultural land. In some cases, agricultural land that has the most opportunity to experience conversion is rice fields. The purpose of this study is to provide an overview of the condition of the rice fields related to the carrying capacity and its suitability to the urban spatial layout of Pangkajene. The method used in this research is a quantitative descriptive analysis of spatial data and secondary data. The area of rice fields in the urban area of Pangkajene in a vulnerable time of 7 years decreased by 149 ha. The results of the calculation of the carrying capacity of rice fields in the Pangkajene urban area in 2020 amounted to 0.27 which is included in class III or low criteria. While the optimal population is 11,102 people. The total of 15.23 ha of land was not suitable for the agricultural planning zone in regional spatial planning. There are still people who build buildings in the agricultural area of 2.99 ha or $0.71 \%$. The open land also exists in the area designated for agricultural activities covering an area of 6.91 ha or $1.63 \%$. The residents also expand their yards in an area devoted to agricultural activities by 5.33 ha or $1.26 \%$.
\end{abstract}

Keywords: Rice Fields, Carrying Capacity, Spatial Planning, Geographic information system

\section{Introduction}

Population growth, economic growth, and land use change are phenomena that always occur together with urban development and growth (Kumar and Sangwan, 2013). Population development and economic growth require land as a place and as a result, there is competition for land use, especially in developed areas (Soemarno, 2013). The growth of an urban area will result in the conversion of agricultural land to non-agricultural land, this indicates that the city is experiencing economic growth (Wunarlan dan Syaf, 2019). However, the continuous and uncontrolled conversion of agricultural land will become a threat not only to farmers and the environment but can also become a national problem (Prihatin, 2016). In some cases, agricultural land that has the most opportunity to experience conversion is rice fields because the location of rice fields is often close to cities and ecosystems. Most of the rice fields are flat topography suitable for the development of urban infrastructure and facilities (lqbal and Sumaryanto in Ningsih et al., 2018)).

Pangkajene urban area is an area that has flat topography. Most of these areas, especially Maritengngae and Watang Pulu areas, have rice fields that are dominated by irrigation (BPS, 2019). This means that most urban areas are productive agricultural land. Productive agricultural land is an important asset in agricultural development because making a new land requires a large investment cost and a long time (Basuki et al., 2010).

The increase in population has an impact on increasing the need for food and shelter, and both require land so that it takes up other land and changes the surrounding land. This change will affect the carrying capacity of the land (Rahayu et al., 2014). This is the same as the Pangkajene urban area. The condition of the population in the Maritengngae and Watang 
Pulu areas has increased in the last 5 years. The area of rice fields in the Maritengngae area in 2010 was 14,495 ha and in 2018 the rice field area was 10,566.3 ha, which means that the area of rice fields has decreased (BPS, 2019).

In terms of increasing or maintaining the value of rice production in Sidenreng Rappang district, especially in the urban area of Pangkajene, a spatial planning policy is needed. Spatial planning also plays a role in reducing land-use change (Takim, 2016). As for the strategy outlined in Regional Regulation Number 5 of 2012, concerning the spatial plan for Sidenreng Rappang district for 2012-2032, namely in article 4 concerning the development of cultivation areas through optimization of area functions in encouraging the economy and community welfare by developing agricultural areas through stipulation and strictly controlling agricultural land area of sustainable food. Optimization and control can be done by providing a spatial picture through a geographic information system (GIS). This allows GIS in the form of maps to be easy to understand and to provide a clear picture. The spatial information from the mapping results is the basis for policymakers in determining policies related to regional development (Sejati et al., 2020).

The purpose of this study will provide an overview of the condition of rice fields related to their carrying capacity and suitability to the urban spatial layout of Pangkajene so that it becomes information material for the government and related stakeholders in formulating policies that are in line with agricultural development.

\section{Methods}

This research was conducted in the urban area of Pangkajene, Sidenreng Rappang district, South Sulawesi. The Pangkajene urban area based on Regional Regulation No. 5 of 2012 is located in a part of the Maritengngae sub-district and partly in the Watang Pulu sub-district. Geographically, the Pangkajene urban area is located between the coordinates $119^{\circ} 45$ '00 "$119^{\circ} 50^{\prime} 00^{\prime \prime}$ East Longitude and $3^{\circ} 54^{\prime} 00$ "- $3^{\circ}$ $57^{\prime} 00 "$ South Latitude.

The method used in this research is a quantitative descriptive analysis of spatial data and secondary data. The descriptive method is used in this research to explain and interpret the data system according to the actual situation (Sugiyono, 2012). The population in this study was the entire rice field use unit in the urban area of Pangkajene. Data is collected through field surveys and requests for data from agencies or literature studies. These data include spatial data on the 2012-2032 Pangkajene urban spatial plan, administrative maps, and road networks, as well as population data from the Central Statistics Agency (BPS).

In identifying the use of rice fields, it is done by digitizing the method on screen in the opensource software QGIS 3.10. Digitization Onscreen is the conversion of data into a digital format that is done on a computer screen by utilizing a variety of geographic information system software (Larasati et al., 2017). This study used high-resolution satellite image data obtained in Google Earth recording years 2013 and 2020. Digitization data On-screen produced a map of the area of rice fields and then became a reference in determining changes in rice fields, analyzing the carrying capacity of rice fields and being a comparison in determining suitability rice fields against the regional spatial plan.

Next, determine the level of carrying capacity of agricultural land. The carrying capacity of agricultural land is the ability of the land to produce agricultural products to support human life so that they can live properly (Muta'ali, 2012). This analysis uses a mathematical formula from a combination of the theory of Odum et al in Muta'ali, (2012), namely:

$$
\sigma=\frac{X}{K} \ldots . .(1)
$$

Information:

$$
\begin{aligned}
& \sigma=\text { Carrying capacity of the land } \\
& \mathrm{x}=\text { Area of harvested land (ha) / } \\
& \text { population (people) } \\
& \mathrm{K}=\text { Minimum physical need (KFM) / food } \\
& \text { crop production / ha / year } \\
& \text { According to Odum et al in Rahayu et al., }
\end{aligned}
$$
(2014), areas that are capable of self-sufficiency in food are areas that meet the minimum physical needs of the population of 1600 calories/person/day or equivalent to $265 \mathrm{~kg}$ of rice/person/year. Meanwhile, an area capable of providing a decent life for the population is equivalent to 650 kilograms of rice/person/year. From this equation, the carrying capacity of agricultural land is divided into 3 classes, namely:

a) Class $I$ if the value of $\sigma>2.47$ : the carrying capacity of agricultural land is high

b) Class II if the value $1 \leq \sigma \leq 2.47$ : optimal carrying capacity of agricultural land

c) Class III if the value of $\sigma<1$ : the carrying capacity of agricultural land is low

The results obtained in calculating the carrying capacity of agricultural land are 
included in the equation for calculating the optimal population (JPO). JPO is the large number of people supported by the results of food crops on agricultural land in an area (Huda et al., 2017). The equation is as follows:

$$
J P O=\sigma \times \text { population }
$$

For the analysis of the suitability of rice fields to the regional spatial plan, it is carried out using an overlay technique. An overlay can be interpreted as a CIS analysis in combining different spatial layers and their attributes to obtain new information (Larasati et al., 2017). In this process, a 2020 rice field map with a spatial plan map for the urban area of Pangkajene, Sidenreng Rappang district, is needed using the QGIS 3.10 software.

\section{Results and Discussion}

\section{Identification of Rice Fields in the Pangkajene Urban Area}

In the process of identifying the use of rice fields into a rice field map in the study area, first, the on-screen digitization accuracy test was carried out on the Google Earth satellite image in 2020. The accuracy test is intended to determine the accuracy in the interpretation or digitization of the image so that it is acceptable. The process of testing the accuracy by conducting a site survey (ground check) to compare the results of digitization with the conditions in the field. The survey results with digitization results then produce a percentage value of overall accuracy (OA) ((Asra et al., 2020). There are 50 survey points conducted in the field. The survey results prove that 46 points are in accordance with the results of digitization, while 4 points are not in accordance with the results of digitization. If this value is entered into the percentage of overall accuracy (OA) the result is 0.92 or $92 \%$. This means that the digitization results can be accepted and become a reference in digitizing the previous year. This is following the opinion (Luthfina et al., 2019) that image classification is acceptable if the results obtained are $\geq 80 \%$. After deemed appropriate, a map of rice fields in 2013 and 2020 was obtained in Figures 1 and 2 below.

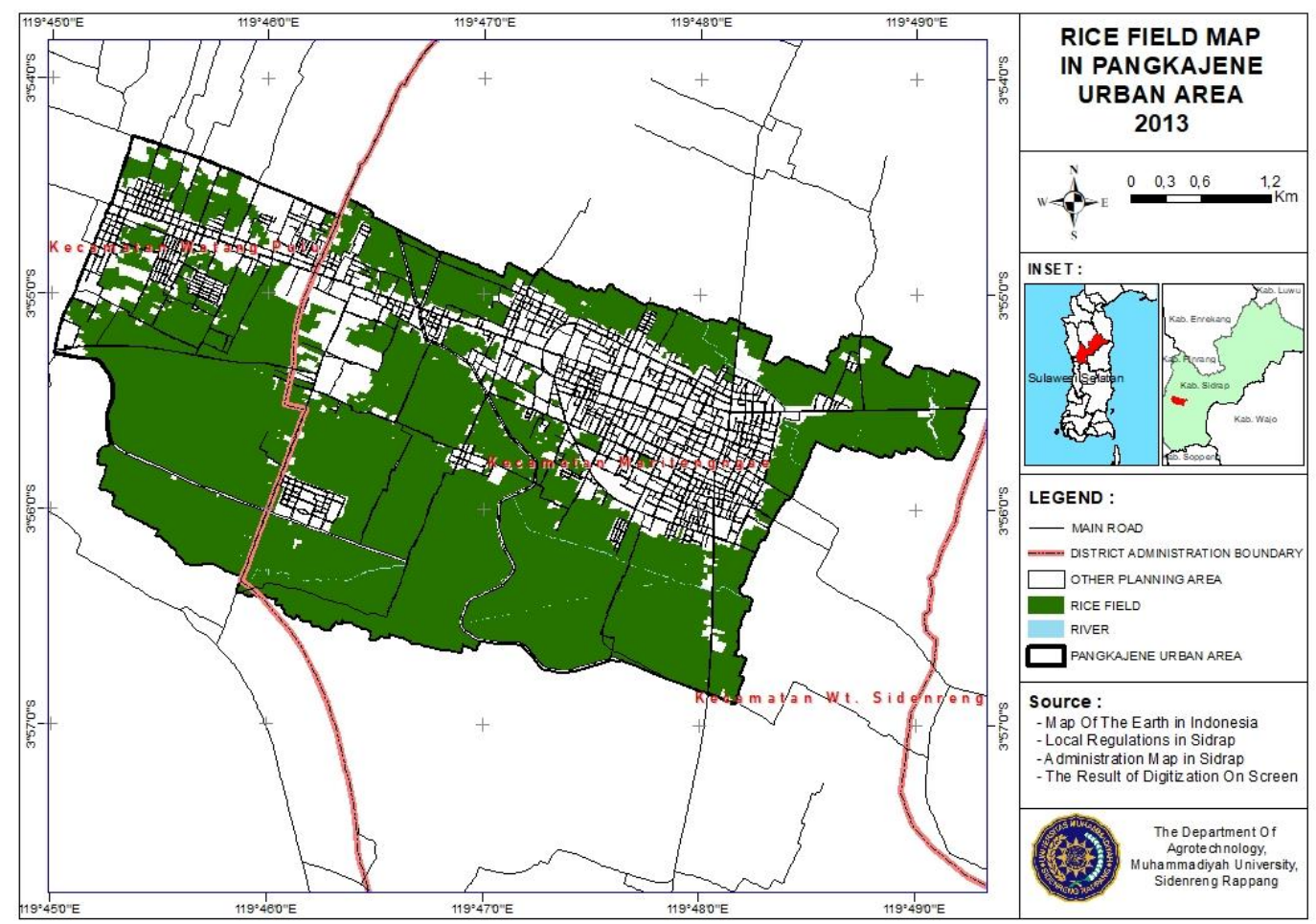

Figure 1. Map of Rice Fields, Pangkajene Urban Area, 2013 


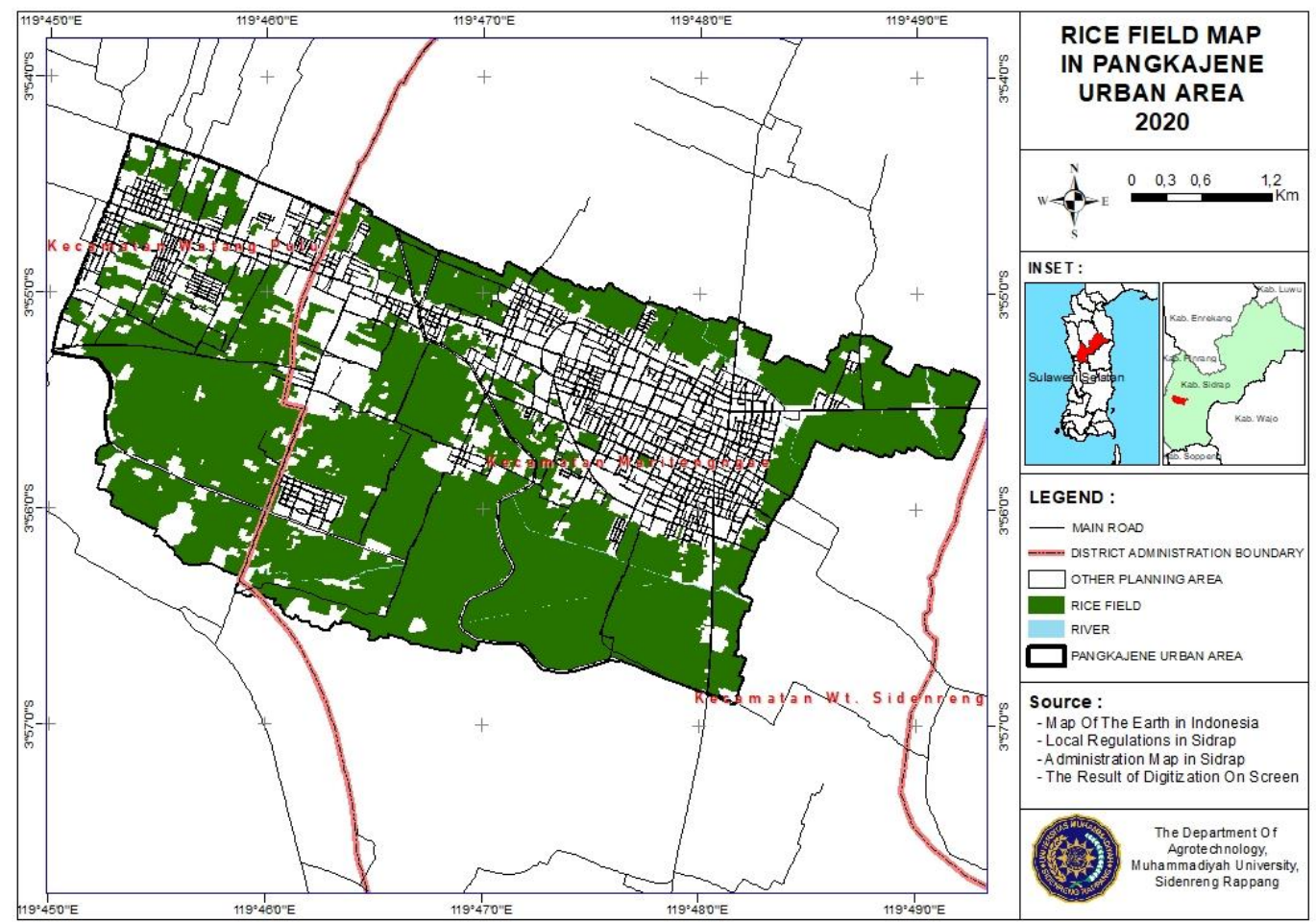

Figure 2. Map of Rice Fields, Pangkajene Urban Area, 2020

Based on the results of the analysis of the geographic information system (GIS) of rice fields in 2013 and 2020, the area of rice fields in the Pangkajene urban area in 2013 was 1377.94 ha or equivalent to $68.04 \%$ of the total area of the whole area. Meanwhile, the rice field area in the urban area of Pangkajene in 2020 was 1228.94 ha or $60.68 \%$ of the total area of the urban area. Based on these results, it can be said that the Pangkajene urban area has changed the function of rice fields. This is evidenced in a 7year vulnerable period, namely 2013 and 2020, the area of rice fields in the urban area of Pangkajene decreased by 149 ha.
Carrying Capacity of Rice Fields in the Pangkajene Urban Area

After obtaining the land area in 2020, then an analysis of the carrying capacity of the land and the optimal population (JPO) was carried out to determine the ability of rice fields in current conditions. This analysis uses equation 1 to measure the carrying capacity of the land, and equation 2 to measure the optimal population (JPO) where the input for population and food crop production is obtained from BPS data (2019), and harvest area data based on analysis system geographic information (CIS). The results of the analysis can be seen in Table 1 below.

Table 1. Carrying Capacity of Rice Fields and Optimal Population in 2020

\begin{tabular}{cccccc}
\hline $\begin{array}{c}\text { Harvested } \\
\text { area (ha) }\end{array}$ & $\begin{array}{c}\text { Total } \\
\text { Population } \\
\text { (Unit) }\end{array}$ & $\begin{array}{c}\text { Food Crop } \\
\text { Production } \\
(\mathrm{Kg} / \mathrm{ha} / \mathrm{yr})\end{array}$ & $\begin{array}{c}\text { The carrying } \\
\text { capacity of } \\
\text { food } \\
\text { agricultural } \\
\text { land }\end{array}$ & $\begin{array}{c}\text { Optimal } \\
\text { Population } \\
\text { (JPO) }\end{array}$ & Information \\
$1,228.94$ & 41,173 & 5,872 & 0.27 & 11.102 .05 & $\begin{array}{r}\text { Urban areas are included in Class } \\
\text { III (Low Criteria), the carrying } \\
\text { capacity value }<1\end{array}$ \\
\hline
\end{tabular}

Source: Analysis Results, 2020

The results of the calculation of the carrying capacity of rice fields in urban areas in 2020 amounted to 0.27 , which means it is included in class III (low criteria). The purpose of the low criterion is that the rice production in the Pangkajene urban area is not able to meet the food needs of the population or it is said that the carrying capacity of rice fields is low / not 
optimal. Rice production in urban rice fields is not able to accommodate the high food needs of the population in urban areas. If residents depend on existing rice fields in urban areas, urban areas have not been able to achieve food security. Because realizing food security according to Government Regulation Number 68 of 2002 concerning Food Security is a condition in which food is fulfilled for households, which has sufficient food availability, both in quantity and quality, is safe, equitable and affordable.

In the results of the Optimum Population Number (JPO) analysis, rice fields in their current condition, namely in 2020, are only able to accommodate 11,102 people. However, when looking at the population of Pangkajene urban areas according to BPS data of 41,173 people, it is necessary to have other rice fields outside the urban areas to support food availability in urban areas so that food security in urban areas can still be overcome. Besides, there need to be land-use activities for other agricultural activities besides using rice fields and diversifying types of food plants to support food needs in urban areas. This is in line with the opinion (Mubarokah et al., 2020), in optimal use of empty land in the form of open land and yards can help increase the number of crops. There needs to be diversification or diversification of food types so that the population does not always depend on foods made from rice. Increasing the ability to produce food for farmers is also needed because it will provide multiple benefits such as the application of environmentally friendly fertilizers, agroforestry, and others.

\section{Suitability of Rice Fields with Pangkajene Urban Spatial Planning}

In knowing the suitability of rice fields with regional spatial planning, a map of urban spatial planning for the 2012-2032 period is needed to determine government policies in spatial planning. In the Pangkajene urban spatial plan map, it has been divided into 22 planning subzones. It includes regional planning devoted to agricultural activities. For a map of agricultural land based on the urban spatial plan of Pangkajene, it can be seen in Figure 3 below.

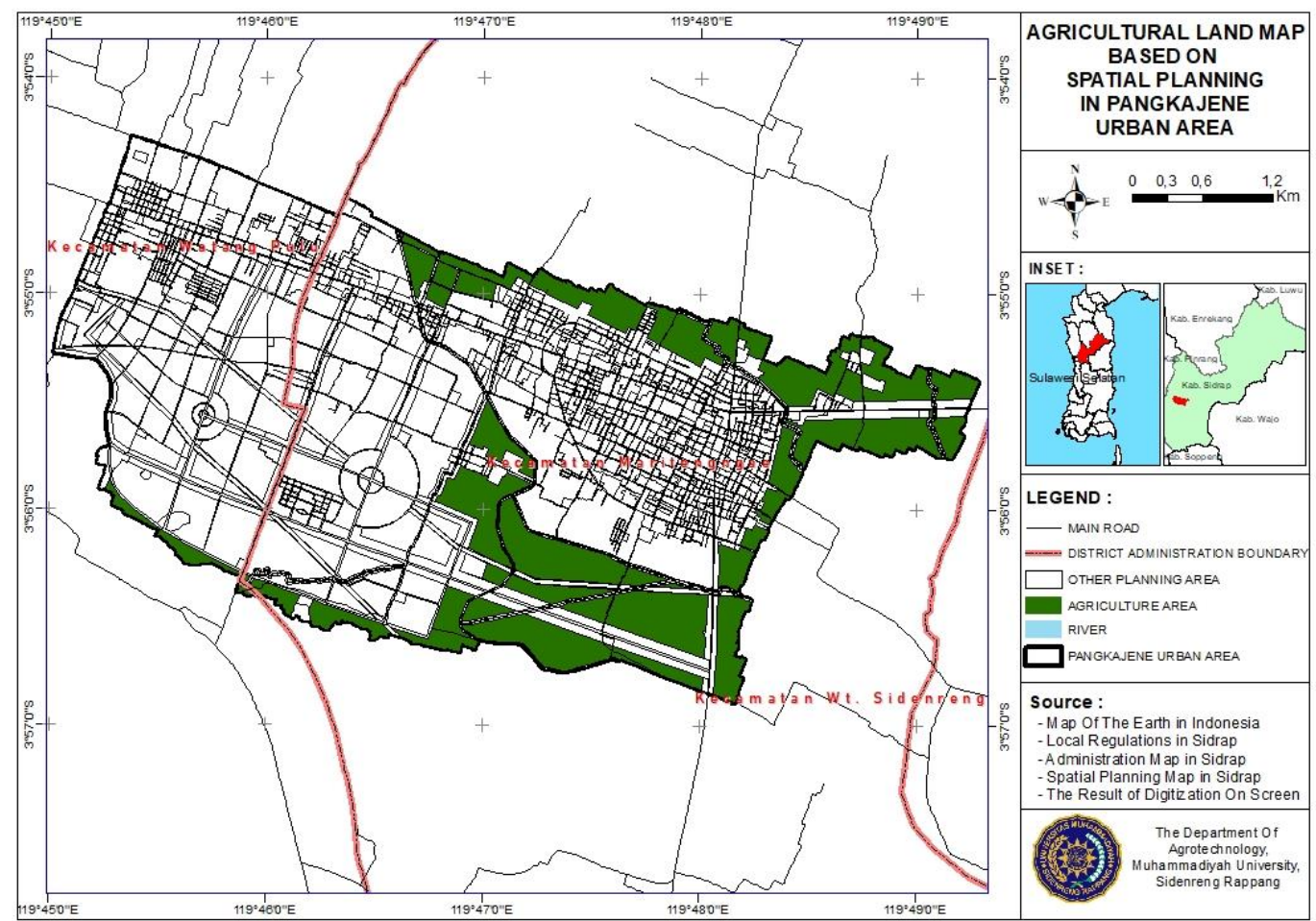

Figure 3. Map of Rice Fields Based on Urban Spatial Planning

Based on the urban spatial plan of Pangkajene, urban areas are not focused on agricultural development areas as evidenced by the area of agricultural land planning covering an area of 424.21 ha. However, looking at the potential of rice fields in urban areas, most of the rice fields are considered to be still productive as evidenced by the flat topography, and most of them are irrigated by irrigation or commonly called irrigated rice fields. 
Furthermore, an overlay process is carried out on the 2020 rice field land use map and the Pangkajene urban spatial plan map to see the suitability of rice fields with the urban spatial

Table 2. Suitability of Rice Fields with Pangkajene Urban Spatial Planning

\begin{tabular}{lccc}
\hline Land & Area (ha) & Percentage (\%) & Suitable with Spatial Planning \\
\hline Buildings in Agricultural Areas & 2.99 & 0.71 & Not suitable \\
Mixed gardens in Agricultural areas & 5.94 & 1.40 & Suitable \\
empty land in Agricultural areas & 6.91 & 1.63 & Not suitable \\
yards in Agricultural areas & 5.33 & 1.26 & Not suitable \\
rice fields in Agricultural areas & 403.03 & 95.01 & Suitable \\
\hline land area agriculture on RTRW & 424.21 & 100 & \\
\hline
\end{tabular}

Results of GIS Analysis, 2020

Based on the analysis of geographic information systems $(G \mid S)$, it was found that several land uses were not suitable the spatial planning. A total of 15.23 ha of land are not suitable for the agricultural planning zone in regional spatial planning. There are still people who build buildings in agricultural areas, covering an area of 2.99 ha or $0.71 \%$. Empty land or open land also exists in the area designated for agricultural activities covering an area of 6.91 ha or $1.63 \%$. The residents also expand their houses in the area devoted to plan. It can be seen that the suitability of rice fields with the detailed regional spatial plan is in table 2 below.

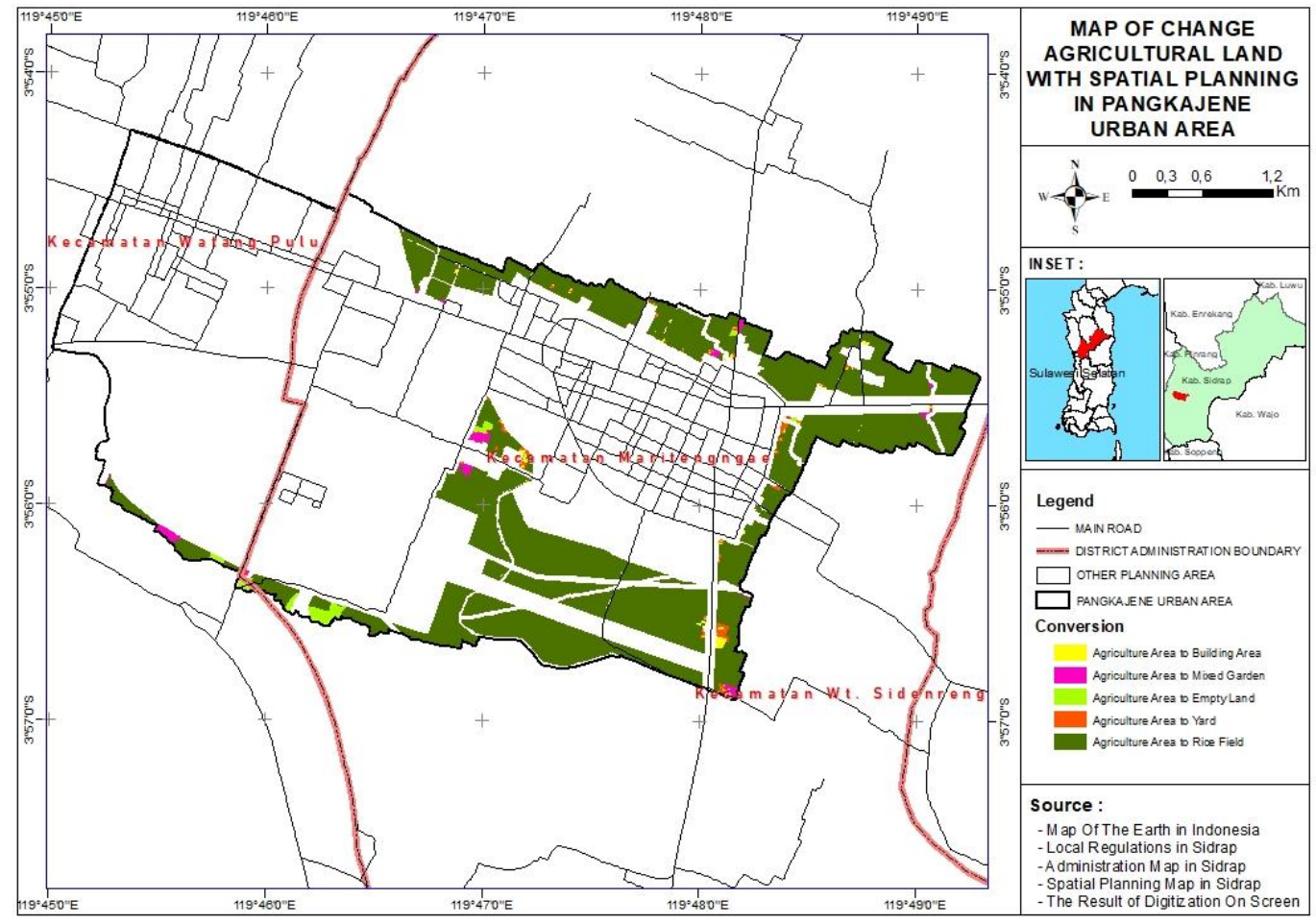

Figure 4. Map of Suitability of Rice Fields with Pangkajene Urban Spatial Planning

Looking at the current conditions that occur in the rice fields in the Pangkajene urban area when linked to the regional spatial plan, most of them are still in the appropriate category. agricultural activities by 5.33 ha or $1.26 \%$. However, as many as 408.97 ha of areas designated as agricultural areas are still in suitable their designation. Based on these data, it can be seen that there are still some residents in the urban area of Pangkajene who use the land not suitable for its designation. Areas that are designated as agricultural areas should not be converted into other land uses. The map of the suitability of rice fields with the urban spatial plan of Pangkajene can be seen in Figure 4 below. 
impacts of land conversion can be overcome by early identification, good communication patterns, and the need for cooperation from various parties. According to (Amir, 2018), the spatial crisis in a region can occur due to the weak competency of human resources in spatial management, the spatial plan has not been qualified, has not become a reference for spatial planning legislation as a support for policies in spatial use and the weak application of laws that occurs. This aspect will lead to development not following the spatial plan, not considering sustainability, environmental carrying capacity, and vulnerability to natural disasters.

\section{Conclusion}

The area of rice fields in the urban area of Pangkajene in a vulnerable time of 7 years has decreased by 149 ha. The results of the calculation of the carrying capacity of rice fields in the Pangkajene urban area in 2020 amounted to 0.27 , which means that it is included in class III or low criteria while the optimal population is 11,102 people.

A total of 15.23 ha of land are not suitable for the agricultural planning zone in regional spatial planning. There are still people who build buildings in the agricultural area of 2.99 ha or $0.71 \%$. Empty land or open land also exists in the area designated for agricultural activities, covering an area of 6.91 ha or $1.63 \%$. Residents also expand their yards in an area devoted to agricultural activities by 5.33 ha or $1.26 \%$.

\section{Acknowledgments}

The author would like to express his gratitude to DRPM KEMENRISTEKDIKTI as a provider of research grants and various parties who have helped carry out this research.

\section{References}

Amir, N. (2018). Aspek Hukum Pengaturan Tata Ruang Terhadap Alih Fungsi Lahan Dalam Rangka Pembangunan Nasional. Jurnal Justiciabelen, 1(1), 120-143. https://doi.org/10.30587/justiciabelen.v1i1. 497

Asra, R., Mappiasse, M. F., \& Nurnawati, A. A. (2020). Penerapan Model CA-Markov Untuk Prediksi Perubahan Penggunaan Lahan DI Sub-DAS Bila Tahun 2036. Agrovital: Jurnal Ilmu Pertanian, 5(1), 1-8.

Basuki, C. T., Purwanto, J., Fajarningsih, R. U., \& Ani, S. W. (2010). Dampak Alih Fungsi Lahan Pertanian Ke Sektor Non Pertanian Terhadap Ketersediaan Beras Di
Kabupaten Klaten Provinsi Jawa Tengah. Caraka Tani: Journal of Sustainable Agriculture, $25(1), \quad 38$. https://doi.org/10.20961/carakatani.v25i1. 15732

Badan Pusat Statistik. 2019. https:// www.bps.go.id. Diakses 05 Agustus 2020

Huda, I. A. S., Suwargany, M. H., \& Anjarika, D. S. (2017). Analisis Daya Dukung Dan Kebutuhan Lahan Pertanian Di Kabupaten Lamongan Tahun 2035. Prosiding Seminar Nasional Geografi UMS, 8(1), 370-380. https://publikasiilmiah.ums.ac.id/handle/11 $617 / 9044$

Kumar, S., \& Sangwan, R. S. (2013). Urban Growth, Land Use Changes and Its Impact on Cityscape in Sonipat City Using Remote Sensing and GIS Techniques, Haryana , India. International Journal of Advanced Remote Sensing and GIS, 2(1), 326-332.

Larasati, N. maulina., Subiyanto, S., \& Sukmono, A. (2017). Analisis Penggunaan Dan Pemanfaatan Tanah (P2T) Menggunakan Sistem Informasi Geografis Kecamatan Banyumanik Tahun 2016. Jurnal Geodesi Undip, 6(4), 89-97.

Luthfina, M. A. W., Bambang, S., \& Suprayogi, A. (2019). Analisis Kesesuaian Penggunaan Lahan Terhadap Rencana Tata Ruang Wilayah Tahun 2010-2030 Menggunakan Sistem Informasi Geografis Di Kecamatan Pati. Jurnal Geodesi Undip, 8(1), 74-82.

Mubarokah, N., Rachman, L. M., \& Tarigan, S. D. (2020). Analysis of Carriying Capacity of Crop Agricultural Land in Cibaliung Watershed, Banten Province. Jurnal IImu Pertanian Indonesia, 25(1), 73-80. https://doi.org/10.18343/jipi.25.1.73

Muta'ali, Lutfi. 2012. Daya Dukung Lingkungan Untuk Perencanaan Pengembangan Wilayah. Badan Penerbit Fakultas Geografi. Yogyakarta.

Ningsih, T. R., Hermon, D., \& Wilis, R. (2018). Analisis Perubahan Lahan Padi Sawah Menjadi Lahan Permukiman Di Kenagarian Tanjung Bingkung Kecamatan Kubung Kabupaten Solok. JURNAL BUANA, 2(4), 114-123.

Peraturan Daerah Kabupaten Sidenreng Rappang. (2012). Rencana Tata Ruang Wilayah Kabupaten Sidenreng Rappang Tahun 2012-2032. Peraturan Daerah Nomor 5 Tahun 2012. Bupati Sidenreng Rappang. Pangkajene.

Prihatin, R. B. (2016). Alih Fungsi Lahan Di Perkotaan (Studi Kasus Di Kota Bandung Dan Yogyakarta). Jurnal Aspirasi, 6(2), 
105-118.

https://doi.org/10.22212/aspirasi.v6i2.507

Rahayu, S., Hadi, P., \& Wijayanti, P. (2014).

Perubahan Daya Dukung Lahan Pertanian

Di Kecamatan Tasikmandu Kabupaten

Karanganyar Tahun 2007-2013.

Pendidikan Geografi, 3(1), 1-15.

RI (Republik Indonesia). (2002). Peraturan Pemerintah Nomor 68 tahun 2002 tentang Ketahanan Pangan. Sekretariat Negara. Jakarta.

Sejati, A. E., Hasan, M., Nursalam, L. O., \& Harianto, E. (2020). Kesesuaian Pemetaan Penggunaan Lahan Permukiman Dengan Kondisi Sebenarnya Di Kecamatan Katobu Dan Kecamatan Duruka Kabupaten Muna. Jurnal Tunas Geografi, 09(01), 55-68.

Soemarno, 2013. Konversi Lahan. Bahan Ajar Mata Kuliah Landuse Planning \& Land Management. Universitas Brawijaya. Malang.

Sugiyono. 2012. Metode Penelitian Kuantitatif Kualitatif dan $R \& D$. CV Alvabeta. Bandung.

Takim, M. H. (2016). Perlindungan Hukum Lahan Pertanian Pangan Berkelanjutan (PIp2b) Di Kabupaten Gresik Terhadap Ijin Usaha Dan Industri. Airlangga Development Journal, 1(4), 63-77.

Wunarlan, I., \& Syaf, H. (2019). Analisis Pengaruh Pertumbuhan Penduduk Dan Produktivitas Lahan Terhadap Alih Fungsi Lahan Perkotaan (Studi Kasus Kota Marisa). Jurnal Perencanaan Wilayah, 4(1), 1-11. 